DOI: 10.12731/2070-7568-2020-4-119-145

УДК 368

\title{
ПЕРСПЕКТИВЫ КИТАЙСКО-РОССИЙСКОГО СОТРУДНИЧЕСТВА В ОБЛАСТИ СТРАХОВАНИЯ
}

\section{Ван Вэньтао}

Статья посвящена состоянием страхового рынка России и Китая. Рассмотрены вопросы деятельности крупнейших страховых компаний России и Китая. проанализированы основные перспективы китайско-российского сотрудничества в области страхования. В эпоху стремительного технологического развития 21 века уровень жизни людей значительно повысился, и циирровая экономика вступила в период всестороннего развития. Стремительное развитие циифровой экономики заложило основу для циифровизации страхового рынка Китая, поэтому страховой рынок имеет иирокие перспективы развития. Страховой рынок-это фиксированная торговая плошадка, такая как страховая биржа. Объектами сделок на страховом рынке являются различные страховые защциты и другие страховые услуги, предоставляемые страховщиками от рисков, с которыми сталкиваются потребители, то есть различные страховые продукты. Основная часть страхового рынка, объект страхового рынка и носитель страхового рынка образуют систему структуры страхового рынка. Эти три элемента взаимосвязань и взаимно ограничивают друг друга для поддержания стабильной работь и здорового развития страховой отрасли.

Цель - определение способов и приемов анализа, применяющих при проведении анализа китайско-российского сотрудничества в области страхования

Метод или методология проведения исследования. В статье использовались теоретические методы, практические методы, методы анализа кейса, статистические методы и сравнительные методы. 
Результаты. Получены наиболее информативныле параметры, показываюшие некоторые аспекты широких перспектив для сотрудничества и развития в сфере страхования между Китаем и Россией.

Область применения результатов. Полученные результаты целесообразно применять экономическими субъектами, осуществляюшими внешнеэкономическую деятельность, одним из элементов которой являются страховые рынки.

Ключевые слова: перспективы; сотрудничество; страхование; деятельность страховых компаний; страховой рынок Китая и страховой рынок России.

\section{PROSPECTS FOR CHINA-RUSSIA COOPERATION IN THE INSURANCE FIELD}

\section{Wang Wentao}

The article is devoted to the state of the insurance market in Russia and China. The issues of the activities of the largest insurance companies in Russia and China are considered. Analyzed are the main prospects of Chinese-Russian cooperation in the field of cooperation in the field of insurance. In the era of rapid technological development in the 21st century, people's living standards have been significantly improved, and the digital economy has entered a period of comprehensive development. The rapid development of the digital economy has laid the foundation for the digitalization of China's insurance market, so the insurance market has broad development prospects. The insurance market is a fixed trading place, such as an insurance exchange. The transaction objects of the insurance market are various insurance protections and other insurance services provided by insurers for the risks faced by consumers, that is, various insurance products. The main body of the insurance market, the object of the insurance market and the carrier of the insurance market form an insurance market structure system. The three are interrelated and mutually restrict each other to maintain the stable operation and healthy development of the insurance industry. 
Purpose. Determination of methods and techniques of analysis used in the analysis of Chinese-Russian cooperation in the field of insurance.

Methodology. The article used theoretical methods, practical methods, case analysis methods, statistical methods and comparative methods.

Results: obtained the most informative parameters showing some aspects of the analysis of broad prospects for cooperation and development in the field of insurance between China and Russia.

Practical implications. The results obtained are expediently applied by economic entities engaged in foreign economic activity, one of the elements of which is insurance markets.

Keywords: prospects; cooperation; insurance; activities of insurance companies; insurance market in China and the insurance market in Russia.

\section{Введение}

Актуальность темы. Страховой рынок Китая - крупнейший в мире и по объемам собираемой премии, и по количеству заключаемых договоров. Жесткое государственное регулирование отрасли не мешает ей стремительно развиваться: ежегодно китайские страховщики собирают премию в размере 1,4 триллиона юаней, что примерно составляет 226 миллиардов долларов. Именно поэтому сотрудничество в данной сфере российских и китайских компаний представляет большой интерес для российской стороны.

Степень разработанности проблемы. Проблема китайско-российского сотрудничества в области страхования наиболее глубоко исследована российскими специалистами. Признанными авторитетами в этой области являются Адамчук Е.А., Акимочкин И.В., Богатенков А.В., Гребенщиков Э.С. и другие.

Значительное место в исследованиях этих ученых отводится сущности страхового рынка, разработке стратегий, методов и моделей управления им. Данные подходы к перспективам китайско-российского сотрудничества в области страхования отличаются большим разнообразием.

Целью данной работы является исследование перспектив китайско-российского сотрудничества в области страхования. 
Для достижения поставленной цели нам необходимо решить следующие задачи:

1) проанализировать состояние страхового рынка Китая и России,

2) рассмотреть деятельность крупнейших страховых компаний Китая и России,

3) проанализировать основные перспективы китайско-российского сотрудничества в области страхования.

Методы, используемые при написании работы, следующие:

1) методы анализа кейса;

2) методы сравнений;

3) теоретические методы;

4) практические методы;

5) статистические методы.

Структура работы. Данная работа состоит из введения, содержательной части, заключения и списка использованных источников.

\section{Состояние страхового рынка России и Китая}

Несмотря на своё слабое развитие и нестабильность, страховой рынок Азии почти догоняет Северную Америку. Темпы роста страхового рынка Азии значительно превышают американские. По результатам 2019 года страховой рынок Северной Америки упал на 0,1\% по сравнению с 2018 годом, а рынок Азии в это время вырос на $14,7 \%$ [1].

В 2019 году Китай занял второе место в списке самых больших страховых рынков мира, годом ранее на второй строчке была Япония.

Китай - основной двигатель роста на развивающихся рынках. В прошлом году рынок страхования жизни в этой стране вырос на $21 \%$, хотя за последнее десятилетие в среднем увеличивался на $14 \%$. Такой быстрый рост достигается в основном за счёт страхования жизни и здоровья. На долю Китая приходится более половины всех премий по страхованию жизни на развивающихся рынках, это 11\% от общего мирового объёма. Крупный международный страховщик Swiss Re прогнозирует, что благодаря высокому темпу роста в Китае будут увеличиваться глобальные премии по страхованию жизни. 
Потенциал китайского рынка огромен. Это подтверждает недавняя сделка, в результате которой французский страховщик АХА приобрёл $100 \%$ акций P\&C. Эта компания входит в топ-20 страховщиков Китая.

До 1995 года в Китае действовала монополия на страхование, которая заморозила рынок. С тех пор многое изменилось, сейчас в стране действует более 150 компаний, в том числе иностранных. Больше половины рынка занимают две страховые компании: China Life Insurance и Ping An Insurance. Они входят в десятку крупнейших страховщиков мира по версии Forbes.

Китайская государственная медицинская страховка имеет следующие нюансы:

- Иностранные работники: иностранцы обязаны оформить медицинскую страховку для получения китайской визы или проверить, покрывает ли их частный план медицинского страхования. Иностранцы из ЕС, которые имеют европейскую карту медицинского страхования (ЕНIC), должны уточнить у своего местного правительства, могут ли они получить доступ к медицинскому обслуживанию в Китае до поездки или переезда.

- Граждане стран, не входящих в ЕС: граждане стран, не входящих в ЕС, должны проверить, есть ли у их страны взаимное медицинское соглашение с Китаем.

- Студенты: студенты университетов могут получить частную медицинскую страховку, либо международный полис в вашей стране, либо китайский план медицинского страхования, когда вы приедете в страну. Если вы выберете первый вариант, вы, как правило, оплачиваете все медицинские услуги наличными, а затем оплачиваете свою страховую компанию, когда возвращаетесь домой после учебы.

- Дети: дети получают бесплатное медицинское обслуживание в Китае.

- Пенсионеры и малообеспеченные. Те, кто не может внести свой вклад в ОМС (например, безработные, пенсионеры, дети, слишком больные, чтобы работать), все еще могут получить бесплатное медицинское обслуживание [2]. 
Правила и положения, касающиеся медицинского страхования китайских виз, регулярно меняются.

Китайская политика в области здравоохранения предлагает различные степени покрытия по следующим вопросам:

- Стационарное лечение: покрывает лечение, которое требует пребывания в больнице на ночь.

- Амбулаторное лечение: покрывает лечение, которое не требует ночевки - обычно оно предоставляется в качестве дополнительного пособия.

- Страхование от хронических заболеваний: покрывает болезни, которые не поддаются окончательному лечению.

- Страхование ранее существовавшего состояния: покрывает болезни, которые существовали до того, как страховка была оформлена; большинство планов будет иметь мораторий на ранее существовавшие условия.

- Страхование на случай чрезвычайной эвакуации: покрывает проезд в ближайший частный медицинский центр, если вы не можете получить адекватную медицинскую помощь в своем районе.

- Охват материнства и новорожденного: охватывает сканы, уроки и уход за матерями, а для новорожденных включает прививки и посещения врачей, а в некоторых случаях - круглосуточную горячую линию с доступом к педиатру. После регистрации может быть период ожидания, когда вы не можете подать заявление на материнство.

- Стоматологическое страхование: большинство граждан Китая платят за частную стоматологическую помощь. Если план медицинского страхования не обеспечивает достаточной защиты, можно рассмотреть вопрос о его расширении.

- Прививки: обычно покрываются как часть амбулаторного плана.

- Пособие по болезни: работодатель должен платить заработную плату по болезни, когда гражданин не работает из-за болезни. Китайский фонд социального страхования финансирует выплату пособий по болезни после трех дней отсутствия работника на рабочем месте в случае болезни. Сумма выплат зависит от средней заработной платы за предыдущие два года [3]. 
Теперь рассмотрим рынок страхования в России. В 2019 году страховые сборы остались на уровне прошлого года за счет разнонаправленных трендов в страховании жизни и страховании ином, чем страхование жизни. Несмотря на то, что страховой рынок, как и экономика в целом, переживает непростые времена в свете ситуации с коронавирусом, по мнению наших респондентов, пессимистичные сценарии, прогнозируемые в первые недели режима самоизоляции, не оправдываются. Если в мае опрошенные руководители страховых компаний прогнозировали падение рынка на 12\% по итогам 2020 года, то на текущий момент они видят ситуацию более оптимистично: по мнению некоторых респондентов, рост рынка может составить до 5\%, а большинство респондентов не ожидает падения более чем на $9 \%$.

Представим наиболее перспективные виды страхования иного, чем страхование жизни (потенциал роста более 10\%) на рисунке 1.

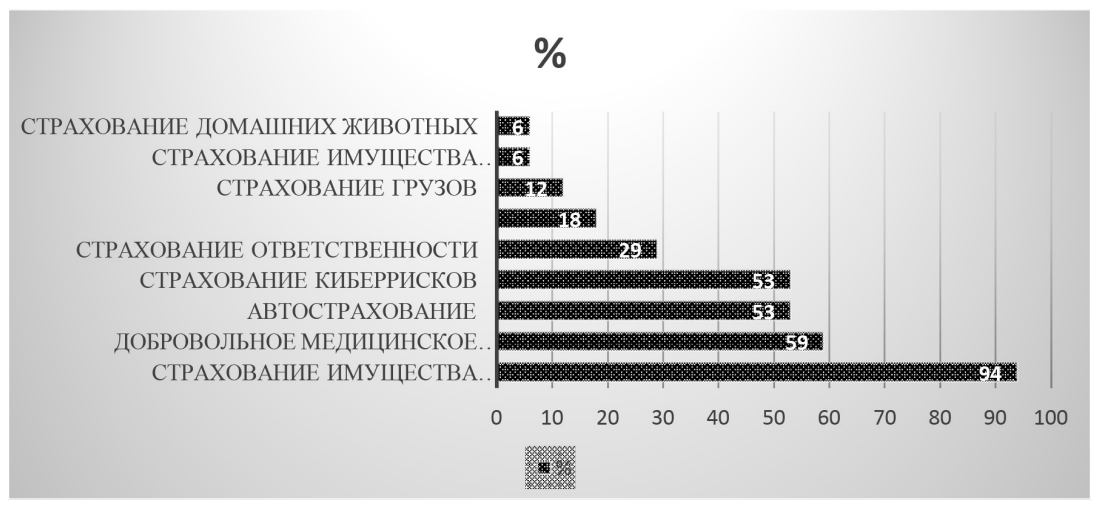

Рис. 1. Наиболее перспективные виды страхования

В мае 30\% респондентов ожидали, что рынок вернется к показателям 2019 года только в 2021 году. К текущему моменту прогнозы страховых компаний стали более оптимистичными. Однако уровень неопределенности остается очень высоким, и прогнозы различаются в зависимости от заложенных предположений (таких как вероятность второй волны коронавируса, прогноз роста экономики и других). 
Представим положительные эффекты для страхового бизнеса в свете ситуации с COVID-19 (рис. 2).

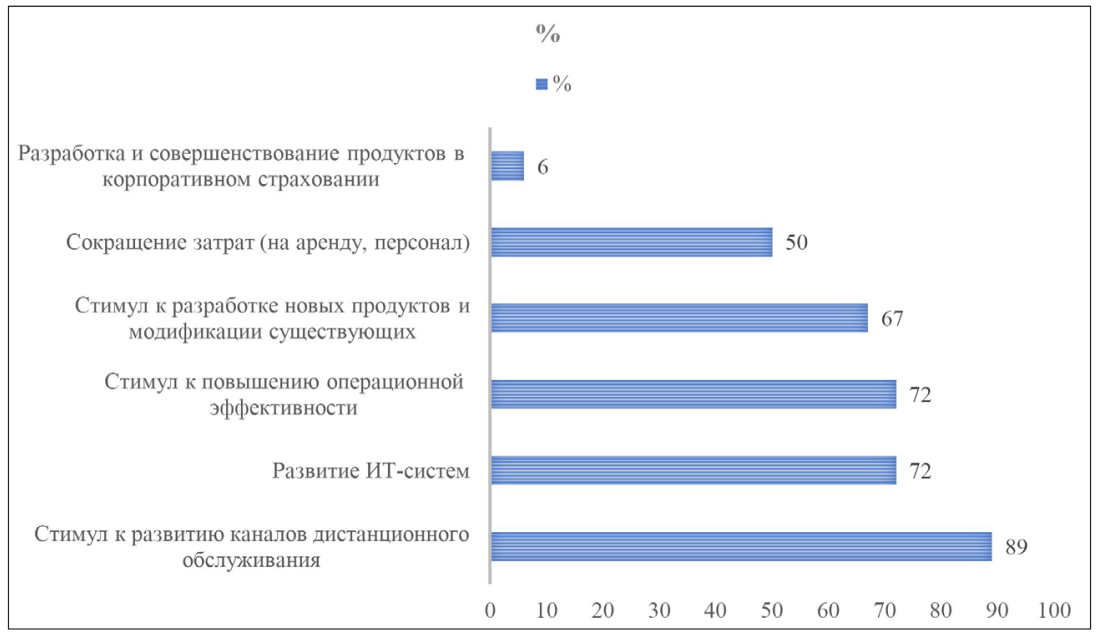

Рис. 2. Положительные эффекты для страхового бизнеса в свете ситуации с COVID-19

Безусловно, возникшие беспрецедентные обстоятельства могут послужить импульсом к «перезагрузке» рынка. Руководители страховых компаний были вынуждены пересмотреть свои взгляды как на организацию рабочего процесса, так и на бизнес в целом.

Безусловно, возникшие беспрецедентные обстоятельства могут послужить импульсом к «перезагрузке» рынка. Руководители страховых компаний были вынуждены пересмотреть свои взгляды как на организацию рабочего процесса, так и на бизнес в целом.

Текущая ситуация стала стимулом для повышения онлайн-доступности страховых продуктов и упрощения процесса урегулирования убытков. Страховщики мотивированы продолжать развитие ИТ-систем и повышать свою операционную эффективность за счет перевода полного цикла взаимодействия с клиентом в онлайн-канал, моделей машинного обучения в продажах, а также за счет использования облачных технологий. Есть все основания полагать, что намечается тенденция к снижению расходов на ведение дел. 
Самыми перспективными направлениями в страховании ином, чем страхование жизни, опрошенные называют ДМС и страхование имущества граждан. Такие ожидания вполне разумны, поскольку данные виды страхования уже продемонстрировали уверенный рост в 2019 году. Как полагают участники нашего исследования, одним из ключевых драйверов рынка ДМС в долгосрочной перспективе может стать развитие телемедицины, коробочных продуктов для розничных продаж, продуктов, связанных с инфекционными заболеваниями, и корпоративных продуктов с франшизой. В то время как рост страхования имущества физических лиц респонденты связывают с принятием закона о страховании жилья от ЧС.

В текущих условиях динамика рынка автострахования напрямую зависит от восстановления спроса на новые автомобили. Кроме того, позитивные ожидания страховщиков связаны с дальнейшей либерализацией тарифов ОСАГО. Подписанный в мае 2020 года закон, учитывающий индивидуальные характеристики водителя в тарифе, - еще один важный шаг на пути либерализации.

Рынок страхования жизни ожидаемо сократился в 2019 году вследствие вступивших в силу стандартов раскрытия информации и неудовлетворенности клиентов низкими доходностями по истекшим полисам ИСЖ. Компании планируют повышать привлекательность данного продукта за счет расширения «рисковой» составляющей покрытия (телемедицина, страхование от НС, страхование от критических заболеваний и т.д.). Кроме того, респонденты хотели бы видеть на российском рынке страхования жизни развитие онлайнканала продаж полисов НСЖ, а также такой продукт, как долевое страхование жизни (unit-linked).

Помимо прочего, руководители страховых компаний возлагают большие надежды на расширение налоговых стимулов и снижение регуляторной нагрузки на сектор в ближайшие 2-3 года.

Страховой рынок России имеет все шансы подойти к 2022 году сильнее, чем он был до кризиса.

Рынок страхования сможет доказать свою состоятельность в сложных экономических условиях, если обеспечит принятые на себя 
обязательства и бесперебойность покрытия. Считаем, что те меры поддержки, которые ЦБ, Минфин нам предоставили, дали возможность дышать, если это перейдет в тенденцию устойчивую, то мы как рынок выйдем из этого кризиса и подойдем к 2022 году, может быть, даже сильнее, чем входили.

ОСАГО для многих небольших страховых компаний оказался спасительным тросом, который компенсировал падение сборов по другим видам страхования в период режима самоизоляции. Вместе с тем, в текущих условиях для небольших региональных компаний важна поддержка на уровне губернаторов. Ее отсутствие может привести к уходу некоторых игроков и росту концентрации рынка, снижению конкуренции. Необходимо предостеречь в том числе Банк России от наметившейся тенденции огосударствления страхового рынка, приведя в качестве примера выдвинутое недавно предложение Минэкономразвития создать госкомпанию по обязательному личному страхованию военнослужащих.

Первый кризис, санкционный, толкнул к созданию “Российского национальный перестраховочной компании”, вторая волна кризиса практически национализировала “Росгосстрах". Вот от этой тенденции хотелось бы предостеречь всех, в том числе рынок. Сейчас наметилась тенденцию к банкострахованию. Например, ипотечное страхование хотят повесить на банкиров. Это еще один путь будет к созданию очень сильных игроков, рыночная сила которых превышать все остальное. Можно тем самым сильно сжать страховой рынок, который вместе с НПФами должен быть институциональным инвестором.

Говоря в целом о страховой отрасли в период пандемии, можно сказать, что, в частности, сегмент страхования жизни после падения вновь начал вызывать большой интерес у клиентов. Вместе с тем из-за снижения покупательной способности и кредитования сборы по некоторым видам страхования могут упасть на 15-30\%.

Часть потерь по сборам будет компенсирована отложенным спросом в 2021 году, когда мы выйдем на рынок полностью. Сложившиеся условия подтолкнут страховщиков к совершенствованию бизнес-процессов. 


\section{Деятельность крупнейших}

\section{страховых компаний России и Китая}

Страховой рынок Китая - крупнейший в мире и по объемам собираемой премии, и по количеству заключаемых договоров. Страховой рынок Китая - перспективный и быстрорастущий по сравнению с рынками развивающихся стран. Быстрое развитие цифровых технологий, таких как большие данные, облачные вычисления, искусственный интеллект и блокчейн сделали неизбежной цифровизацию страхового рынка.

В последние годы китайский страховой рынок рос в лихорадочном темпе. В период с 2000 по 2014 год промышленность выросла примерно на $1200 \%$. В этот же период большинство крупнейших китайских страховых компаний зарегистрировали акции на Гонконгской фондовой бирже и других биржах в рамках усилий по реформированию отрасли за счет сокращения государственного контроля, повышения прозрачности и подверженности компаний требованиям рынка и акционеров. Сегодня крупнейшие страховые компании в Китае входят в число крупнейших компаний в мире по рыночной капитализации.

China Life Insurance Co., Ltd.

С рыночной капитализацией около \$107 млрд. China Life Insurance Co., Ltd. (NYSE: LFC) является крупнейшей страховой компанией в Китае и одной из ведущих страховых компаний в мире. Современная жизнь в Китае отталкивается от создания Китайской Народной Республики в 1949 году. Компания управляет страхованием жизни и имущества, а также предоставляет услуги по управлению активами и другие финансовые услуги.

China Life поддерживает значительную общенациональную сервисную сеть с почти 750000 специализированными агентами и более 60000 офисами. Клиентская база компании приближается к 200 миллионам человек в индивидуальном и групповом страховании жизни, политике долгосрочного медицинского страхования и аннуитетах. China Life зарегистрирована на Шанхайской фондовой бирже, Гонконгской фондовой бирже и Нью-Йоркской фондовой бирже [4]. 
Ping An of China

Ping An of China была основана в 1988 году и в 2004 году провела первичное публичное размещение (IPO). В то время как компания начала свою деятельность как компания по страхованию имущества и страхования от несчастных случаев, с тех пор она расширилась в сфере страхования жизни, банковского дела, онлайн-финансовых услуг и управления активами с заявленной целью стать всеобъемлющим поставщиком финансовых услуг. Он имеет рыночную капитализацию около 90 миллиардов долларов.

Ping An насчитывает более 225000 штатных сотрудников и партнеров с более чем 625000 агентов по продажам в Китае. Компания насчитывает более 89 миллионов клиентов в своих подразделениях. Ping An зарегистрирован на Шанхайской фондовой бирже и Гонконгской фондовой бирже.

China Pacific Insurance

China Pacific Insurance Group является интегрированным страховым провайдером, предлагающим страхование имущества и пострадавших, страхование жизни и перестрахование, а также услуги по управлению активами и инвестициям. Компания насчитывает более 300000 агентов и обслуживает около 80 миллионов клиентов по всей стране. China Pacific Insurance прослеживает свои корни до 1991 года. Она была зарегистрирована на Шанхайской фондовой бирже в 2007 году и Гонконгской фондовой бирже в 2009 году. Она имеет рыночную капитализацию более чем в 33 миллиарда долларов. China Pacific - одна из ведущих компаний по страхованию грузов, хотя все компании из данного списка занимают активную позицию в этом.

People's Insurance Company of China Group

Народная страховая компания China Group была основана в 1949 году. Сегодня ее дочерние компании насчитывают более 300 миллионов клиентов в сфере страхования имущества и страхования от несчастных случаев, страхования жизни, медицинского 
страхования и недвижимости. Его наиболее существенной дочерней компанией является компания PICC Property and Casualty Company, которая продает широкий спектр продуктов страхования жизни, включая авто, домовладельцев, коммерческую недвижимость и сельскохозяйственные полисы. Народная страховая компания China Group владеет примерно 69\% акций PICC Property and Casualty. Компания зарегистрирована на Гонконгской фондовой бирже, и её рыночная капитализация составляет около 21 миллиарда долларов [5].

New China Life Insurance

New China Life Insurance Company была основана в 1996 году и быстро вошла в пятерку первых компаний в отрасли. В то время как основным бизнесом компании остается страхование жизни, она также имеет растущие деловые интересы в инвестиционной отрасли и отрасли здравоохранения. New China Life Insurance насчитывает более 26 миллионов клиентов, 175000 агентов и 1600 предприятий по всей стране. Компания была зарегистрирована как на Гонконгской фондовой бирже, так и на Шанхайской фондовой бирже в 2011 году. Она имеет рыночную капитализацию более 17 миллиардов долларов [6].

Далее рассмотрим страховые компании России.

По итогам 1 квартала 2020 года лидерами по объему собранных страховых премий по страхованию иному, чем страхование жизни, стали АО «СОГАЗ» (доля на страховом рынке - 28,3\%), АО «АльфаСтрахование» $(6,3 \%)$ и СПАО «Ингосстрах» $(6,1 \%)$. Крупнейшие компании по взносам сегментах обязательного страхования - АО «СОГАЗ», СПАО «РЕСО-Гарантия» и АО «АльфаСтрахование». В сегментах добровольного страхования иного, чем страхование жизни, лидируют АО «СОГАЗ», АО «АльфаСтрахование» и СПАО «Ингосстрах». В топ-3 по премиям по страхованию жизни по итогам 1 квартала 2020 года вошли ООО СК «Сбербанк страхование жизни», ООО «СК СОГАЗ-ЖИЗНЬ» и ООО «АльфаСтрахование-Жизнь». 
Топ-10 российских страховых компаний по объему сборов за 2019 год представлен в таблице 1.

Таблицча 1.

Топ-10 российских страховых компаний по объему сборов за 2019 год

\begin{tabular}{|l|r|r|r|}
\hline \multicolumn{1}{|c|}{ Компания } & $\begin{array}{r}\text { Доля рынка } \\
\text { в } 2019 \text { году }\end{array}$ & $\begin{array}{r}\text { Изменение сборов } \\
\text { премий в 2019 году }\end{array}$ & $\begin{array}{c}\text { Изменение доли } \\
\text { рынка в 2019 году }\end{array}$ \\
\hline 1. СОГА3 & $23,2 \%$ & $1 \%$ & 0 п.п. \\
\hline 2. Сбербанк Страхование & $11,7 \%$ & $-12 \%$ & -2 п.п. \\
\hline 3. АльфаСтрахование & $11,1 \%$ & $4 \%$ & 0 п.п. \\
\hline 4. Ингосстрах & $76 \%$ & $13 \%$ & 1 п.п. \\
\hline 5. РЕСО & $70 \%$ & $7 \%$ & 0 п.п. \\
\hline 6. Росгосстрах & $6,2 \%$ & $24 \%$ & 0 п.п. \\
\hline 7. ВСК & $6,1 \%$ & $-4 \%$ & 0 п.п. \\
\hline 8. Ренессанс & $4,8 \%$ & $1 \%$ & 0 п.п. \\
\hline 9. Согласие & $2,4 \%$ & $8 \%$ & -1 п.п. \\
\hline 10. КапиталЛайф & $1,4 \%$ & $-26 \%$ & \\
\hline
\end{tabular}

1. АО «СОГАЗ»

Страховая Группа «СОГАЗ» основана в 1993 году и является лидером российского страхового рынка.

Страховая Группа «СОГАЗ» предоставляет более 100 программ страхования для частных лиц и предприятий разных сфер деятельности. Группе доверяют свою страховую защиту системообразующие российские корпорации и их работники. Ежедневно Страховая Группа «СОГАЗ» выплачивает в среднем более 290 млн рублей в качестве возмещения по страховым случаям

2. АО «АльфаСтрахование»

Группа «АльфаСтрахование» - крупнейшая частная российская страховая группа с универсальным портфелем услуг, включающим как комплексные программы защиты интересов бизнеса, так и широкий спектр страховых продуктов для частных лиц.

Группа «АльфаСтрахование» имеет репутацию надежной и устойчивой компании. Сегодня по своим обязательствам Группа отвечает собственными средствами - 31,7 млрд руб. Уставный капитал компании составляет 15 млрд руб. 
3. СПАО «Ингосстрах».

СПАО «Ингосстрах» - одна из крупнейших российских страховых компаний, стабильно входит в Топ 10 страховщиков РФ. Относится к категории системообразующих российских страховых компаний. Наиболее медиа-активный страховщик, три года подряд занимает первое место в рейтинге наиболее упоминаемых в прессе страховых компаний. Полное наименование - Страховое публичное акционерное общество «Ингосстрах», номер в реестре страховых компаний - 928, лицензии: СИ №0928, СЛ №0928, ОС №0928-03, ОС №0928-04, ОС №0928-05 и на осуществление перестрахования ПС № 0928, выданные 23.09.2015 и ОС №0928-02 от 28.09.2016 г., все лицензии без ограничения срока действия.

\section{Основные перспективы китайско-российского сотрудничества в области страхования}

Новые страховые технологии стали активно использоваться также в сфере урегулирования убытков, пресечения случаев страхового мошенничества и т.д. Например, страховая группа PingAn, одна из самых продвинутых в области Insurtech, начала бороться с мошенничеством в медицинском страховании с помощью технологий, связанных с искусственным интеллектом и "большими данными" (big data).

В страховой индустрии большие данные - это несомненное развитие. Они предоставляют ценную информацию по всем аспектам деятельности и эффективности компании - от поведения потребителей до практики андеррайтинга и окупаемости маркетинговых кампаний. Компании, которые хотят использовать эту информацию для практического анализа, обращаются к анализу больших данных.

В 2021 году китайско-российского сотрудничество в сфере страхования будет больше, чем просто цифры. Тенденции указывают на то, что мы можем увидеть новые стратегии китайско-российского сотрудничество в сфере страхования при помощи больших данных, которые помогут компаниям сделать еще больше с их информацией. Вот некоторые из последних тенденций в области больших данных 
для страхования и как вы можете использовать информацию, к которой у вас уже есть доступ, чтобы опередить своих конкурентов.

Тенденции китайско-российского сотрудничества в сфере страхования будут представлены ниже.

1) Машинное обучение

Одна из наиболее актуальных проблем для страховых компаний сегодня заключается в том, как наиболее эффективно и точно просеять множество собранных ими данных. Просто не хватает рабочей силы или часов в день, чтобы максимизировать рентабельность инвестиций в страховые данные и получить полезную информацию из этой информации.

То есть до появления машинного обучения. Благодаря возможностям машинного обучения решения для анализа страховых данных могут обрабатывать данные с более высокой скоростью с повышенной точностью и эффективностью. Машинное обучение может использоваться задним числом для наборов исторических данных, которые уже есть у страховщиков, а также для активного поиска новых способов улучшения операций. Благодаря машинному обучению данные страхования теперь можно использовать для улучшения:

- Ценовые стратегии

- Рекламный контент

- Обработка претензий

2) Прогнозная аналитика

Страховая отрасль в целом зависит от прогнозирования рисков и вознаграждений, и один из способов, с помощью которого многие страховщики делают это, заключается в прогнозной аналитике. Прогнозная аналитика берет большие данные, собранные страховщиками, и использует их для наиболее точного и точного расчета, среди прочего:

- Ценообразование и выбор риска

- Претензии по сортировке

- Новые тенденции

Согласно опросу New China Life Insurance Company, болеe 90\% страховщиков утверждают, что модели оказали положительное влияние на точность оценки, коэффициент потерь и прибыльность. Таким 
образом, результаты широкого использования прогнозирующей аналитики в страховании привели к более точным и более целесообразным процессам в разных операциях. И на сегодняшнем быстро меняющемся рынке операторы не могут позволить себе идти медленно.

3) Конфиденциальность данных

В то время как страховщики имеют в своем распоряжении огромные объемы данных, новые законы и правила меняют способы работы страховых компаний и их аналитических групп.

Общее положение о защите данных (GDPR) стало законом в Европейском союзе в 2018 году, что вызвало всемирную проверку защиты данных потребителей. GDPR описывает, какие данные о потребителях можно собирать и как, и аналогичные законы были приняты в Китае. В стране имеются своего рода нормативные положения о защите данных.

Очень важно, чтобы страховщики использовали гибкую и масштабируемую систему данных, чтобы они могли оставаться в соответствии, так как законы и нормативные акты продолжают меняться со временем.

4) Интернет вещей

Потребность в большей безопасности и регулировании данных в значительной степени обусловлена огромными объемами данных, к которым мы теперь имеем доступ. С созданием Интернета вещей (IoT) мы создали практически непостижимые объемы данных - каждый день генерируется 2,5 триллиона квинтиллионных фрагментов данных. Для сравнения: за последние два года было получено 90\% мировых данных [7].

ІоТ и его роль в аналитике больших данных в страховании практически безграничны. Это дает страховщикам доступ и понимание в отличие от всего, что у них было раньше, и может повлиять на все сферы бизнеса. В этом году данные страхования ІоТ будут использоваться для улучшения, среди прочего:

- Оценка риска

- Маркетинговые кампании

- Обработка претензий

- Утечки претензий

- Цены на продукцию 
5) Неструктурированные данные

Наиболее распространенными данными, используемыми в страховой аналитике, являются так называемые структурированные данные. Эти данные предоставляются поставщиками напрямую, такие как имя, адрес, пол, возраст и т. д. И могут быть введены в стандартные формы и таблицы. Эти данные просты, доступны и пригодны для использования, но они не рисуют всю картину. Новый рубеж для анализа страховых данных - это неструктурированные данные [21].

Неструктурированные данные включают в себя такие вещи, как данные социальных сетей, мультимедиа или письменные отчеты. Новые технологии, такие как IоT, создали метод извлечения и анализа неструктурированных данных, создавая еще более надежный профиль клиентов и потребителей. Данные социальных сетей даже использовались для выявления случаев мошенничества со страховкой и для общения с клиентами. Большие данные, которые охватывают эту информацию, содержат основную, ранее отсутствовавшую часть аналитической головоломки.

6) Искусственный интеллект

ИИ нарушает пространство страхования тем, как страховщики обрабатывают претензии, страхуют и даже обслуживают клиентов. Тем не менее, ИИ также является ценным инструментом в области больших данных страховых операций, поскольку он выступает в качестве центрального источника энергии, обеспечивая мощные автоматизированные инструменты, такие как машинное обучение и прогнозная аналитика, которые делают возможными возможности цифрового страхования [8].

ИИ берет все данные, сгенерированные на сегодняшнем рынке, - от поведения в Интернете до телематики и исторических данных - и превращает их в действенные идеи. Недавнее исследование IBM обрисовало общую картину того, как ИИ улучшит аналитику больших данных в страховании, включая:

- Увеличение скорости [22]

- Оптимизация процессов

- Генерация новых идей [9] 
7) Увеличение доступности данных

Это общепризнанный факт, что страховщики Китая имеют в своем распоряжении непостижимое количество больших данных, и что эти безграничные данные помогают повысить точность и эффективность, как никогда раньше [23]. Тем не менее, при таком огромном объеме данных, как страховщики могут быть уверены, что они работают со своими данными наиболее эффективным способом из возможных?

Это то, что известно как доступность данных - продукты и услуги, которые обеспечивают постоянную доступность данных с требуемым уровнем производительности в ситуациях от нормального до «катастрофического». Чтобы быть конкурентоспособными в современной страховой отрасли, операторы должны иметь системы, обеспечивающие высокий уровень доступности данных в любое время. [24]Этот уровень скорости обеспечивает другие расширенные функции в области данных страхования, такие как машинное обучение, прогнозная аналитика и IоT.

8) Блокчейн-данные

Блокчейн - уникальная, сверхбезопасная система данных, которая сделала возможной Биткойн - сейчас начинает трансформировать страховую индустрию. Данные блокчейна «практически нетлены» благодаря своей конструкции. В статье, подробно описывающей его влияние на страховую индустрию, Forbes описывает данные блокчейна как блоки данных, которые «ссылаются на предыдущий блок и имеют метку времени и даты», которые нельзя изменить.

Полное влияние данных блокчейна в страховой аналитике еще предстоит реализовать, но потенциал многоуровневый. На самом базовом уровне это обеспечит еще более безопасный обмен данными между клиентами и страховщиками, повысив эффективность и прозрачность. Недавний отчет от РwC выделил множество других применений блокчейна в аналитике страхования больших данных, которые включают:

- Создание приложений, основанных на оценке рисков, экономия от 5 до 10 миллиардов долларов ежегодно 
- Более быстрая обработка претензий и оплата покупателям

- Снижение утечек требований и мошенничества, экономия на $15-25 \%$ для страховщиков

- Повышение точности и легитимности данных, соблюдение правовых норм [10].

9) Телематика

Телематика - использование сенсорной технологии для сбора и передачи данных в режиме реального времени на большие расстояния - является последней тенденцией в области сбора данных и страхования. Люди начали выбирать планы, которые анализируют данные их носимых и автомобилей, чтобы лучше информировать свои страховые полисы, в надежде получить более дешевые премии [19].

В новом исследовании прогнозируется, что уровень использования личных страховых полисов телематики, по оценкам, вырастет с 1,5\% по состоянию на декабрь 2015 года до 10,3\% в 2020 году, что представляет собой увеличение с 12 миллионов пользователей до почти 90 миллионов к концу 2020 года. интересный вывод из широкого использования телематики, тем не менее, является ее способность глубоко изменить поведение клиентов. Поскольку их движения отслеживаются, потребители более склонны к безопасному вождению, что, в свою очередь, существенно экономит страховые компании в процессе рассмотрения претензий [11].

Наличие хороших данных - это одно. Знание, как максимизировать его полезность, является чем-то совершенно другим. Существуют различные платформы, инструменты и стратегии, которые страховщики могут использовать для максимально эффективного использования своих данных, но, независимо от подхода, операторы должны иметь возможность собирать, управлять, анализировать и представлять отчеты по этим данным быстро и точно [12].

Страховая отрасль сейчас требует абсолютной скорости и точности, особенно с данными. Операторам, которые ищут решения для анализа больших данных, нужны платформы и инструменты, которые дают им время на анализ, исключая время, затрачиваемое 
на сбор. Страховщики, которые наилучшим образом используют эти инструменты, лучше всего оснащены для того, чтобы предоставить клиентам ожидаемый опыт, трансформируя их бизнес-практику с помощью технологии больших данных следующего поколения [13].

Перспективы китайско-российского сотрудничества в области страхования обширны. Для решения проблем предлагаются следующие направления совершенствования: [20]

- увеличение государственного финансирования здравоохранения через систему ОМС.

- внедрение механизмов финансового планирования и оплаты страховой помощи, которые простимулируют рост эффективности использования ресурсов в системе страхования [14].

- создание устойчивой финансовой основы [16].

- программа оказания медицинской помощи населению должна быть бездефицитной [17].

- усиление государственного регулирования оказываемой в государственных и муниципальных лечебно-профилактических учреждениях платной медицинской помощи [25].

- необходимо обязать платить работодателей и местные органы власти страховые взносы за своих работников [18].

Важным аспектом является выявление нецелевых использований страховых средств [15].

По мере углубления экономических и торговых отношений между Китаем и Россией сотрудничество в области страхования между двумя сторонами продолжало расширяться. У двух стран есть широкие возможности для сотрудничества в области сотрудничества в области страхования туризма, финансирования строительства крупных проектов и защиты от рисков, сотрудничества в сфере перестрахования, а также сотрудничества и развития в ключевых областях страхования. C нетерпением ожидая перспектив сотрудничества между двумя сторонами, первая заключается в создании надежного механизма сотрудничества в страховой отрасли для содействия взаимному обмену; вторая - в укреплении стыковочного сотрудничества страховой отрасли и повышении уровня обслуживания; тре- 
тья - в сотрудничестве в новых ключевых областях и расширении сферы услуг в страховой отрасли.

Цифровая экономика Китая быстро развивается. Технология облачных вычислений, технология больших данных и технология искусственного интеллекта являются ключевыми технологиями, влияющими на развитие цифровой экономики [27]. Среди них китайские интернет-компании уже внедрили независимые инновации в области технологий облачных вычислений и технологий больших данных. Таким образом, цифровая экономика Китая вышла на более высокий уровень в мире. Укрепление сотрудничества между Китаем и Россией в области страхования поможет России извлечь уроки из китайских технологий облачных вычислений, технологий больших данных и технологий искусственного интеллекта. Это также поможет России изучить передовой управленческий опыт, технологии управления и корпоративную культуру китайских компаний, а также поможет привлечь Крупные страховые компании из Китая Страховые и страховые компании из других развитых стран приехали инвестировать в Россию. Взаимные инвестиции Китая и России в сфере страхования способствуют быстрому развитию цифровой экономики России и повышают уровень открытости страны.

\section{Заключение}

В ходе написания данной работы были сделаны следующие выводы.

Сотрудничество России и Китая в страховании охватывает все виды: имущественное страхование, страхование строительных рисков, морское страхование, энергетика и прочее

Китайская экономика выросла примерно на 6,8\% в реальном выражении в 2019 году, что немного сильнее, чем в 2018 году. В секторах услуг и потребления были сильные позиции и устойчивая экспансия в новые стратегические отрасли. Рост промышленного производства оставался стабильным, а рентабельность предприятий улучшалась. Рост экспорта к последнему кварталу замедлился, но показатели за весь год были лучше, чем в 2018 году. Инфляция оставалась умеренной в 2019 году. Общий индекс потребительских 
цен вырос в среднем на 1,5\% за первые 10 месяцев 2019 года. Цены производителей инфляция ускорилась до 6,5\% за тот же период. По прогнозам, премии за жизнь будут расти в среднем на 9,3\% в год в реальном выражении с 2021 по 2028 год.

В отличие от зарубежных компаний российские не понесли существенных убытков и «практически не пострадали в результате пандемии». Это объясняется низким уровнем страхового покрытия тех рисков, которые реализовались в результате пандемии, и соответствующими карантинными мерами, введенными властями.

Big Data - это основа сотрудничества страховых компаний России и Китая, работа которых полностью основана на информации: статистике, сведениях о клиентах, страховых случаях и вероятностях их наступления, а также финансовой оценке всех этих данных. «Большая тройка» современных информационных технологий (большие данные, машинное обучение и интернет вещей) увеличивают прибыль страховщиков, прогнозируя потребности текущих и находя новых клиентов, а также уменьшают их затраты, сокращая выплаты по мошенническим операциям.

Китай и Россия имеют широкие перспективы для укрепления сотрудничества в сфере страхования, которые в условиях цифровой экономики.

В настоящее время можно говорить об успешном взаимодействии между российскими и китайскими компаниями в сфере страхования туристов.

\section{Список литературы}

1. Адамчук Е.А. Тенденции мирового рынка страховых услуг и некоторые ключевые факторы, определяющие его конъюнктуру // Страховое дело. 2012. N 10-11. С. 30-33.

2. Акимочкин И.В. Тенденции развития мирового страхового рынка // Страховое дело. 2010. N 11. С. 50-53.

3. Артеменко Д.А. Финансовые риски в модели обязательного медицинского страхования / Д.А. Артеменко, А.М. Чилилов // Финансы. 2019. N 8. C. $58-64$. 
4. Архипов А.П. Будущее медицинского страхования: больше ясности не становится // Финансы. 2016. N 11. С. 54-58.

5. Архипов А.П. Можно ли обойтись без единой системы медицинского страхования? // Финансы. 2018. N 1. С. 34-38.

6. Богатенков А.В. Китайский страховой рынок накануне вступления КНР в ВТО // Страховое дело. 2001. N 12. С. 42-44.

7. Гребенщиков Э.С. Рабочая модель развития и целевые показатели страхового рынка 2021 год // Финансы. 2019. N 2. С. 44-47.

8. Гребенщиков Э.С. Страховой рынок Китая: темпы, масштабы и эксперименты // Финансы. 2017. N 1. С. 38-44.

9. Ковалевская А.С. Страхование от несчастных случаев и профессиональных заболеваний: зарубежный опыт / А.С. Ковалевская, О.А.Феоктистова // Финансы. 2017. N 1. С. 45-49.

10. Левицкий Л. Совет Федерации намерен сделать страховую медицину реальной // Рос. Федерация сегодня. 2018. N 6. С. 77-81.

11. Линденбратен А.Л. Методические подходы к оценке качества организации медицинской помощи // Здравоохранение. 2015, № 1. С. 74-78.

12. Мартынова А.А. Правовое регулирование системы финансирования обязательного медицинского страхования // Финанс. право. 2019. N 7. С. 44-47.

13. Семенихин В.В. Страховые взносы. Учебно-практическое пособие. М.: ГроссМедиа, 2017. 462 с.

14. Сидоров С.В. Правовая природа договоров в сфере обязательного медицинского страхования / С.В. Сидоров, Н.Ю. Чернусь // Рос. юрид. журнал. 2017. N 3. С. 164-171.

15. Тесля П.Н. Тренды страховой медицины // ЭКО. 2016. N 11. С. 22-38.

16. Ма Веньян. Цифровая экономика: открытие новых возможностей в традиционных отраслях и новых форматах. Пекин: Демократия и строительная пресса, 2017. С. 207-258.

17. Хуан Чжо. Сила цифровых финансов: расширение возможностей реальной экономики. Пекин: Пресса Китайского университета Жэньминь, 2018. С. 230-260.

18. Коу Ефу. Синяя книга страхования, анализ развития страхового рынка Китая. Пекин: Китайское экономическое издательство, 2017. С. 38-85. 
19. Се Шоугуан. Синяя книга автомобиля и страхования: Отчет о развитии китайского автомобиля и страхования BIG data. Пекин: Академическая пресса по социальным наукам, 2020. С. 188-237.

20. Чжао Чжаньбо. Интернет-страхование. Пекин: Столичный университет экономики и бизнеса Prss, 2017. С. 3-32.

21. Ма Хуатэн. Цифровая экономика: новый импульс роста инноваций в Китае. Пекин: China CITIC Press, 2017. С. 253-260.

22. Тан Сяо. Цифровая экономика: новые технологии, новые модели и новые отрасли, влияющие на будущее. Пекин, People's Post and Telecommunications Press, 2019. С. 63-77.

23. Чжу Цзиньюань, Лю Юн, Вэй Ли. Страховые технологии. Пекин: China CITIC Press, 2018. C. 217-257.

24. Ван Сюйцзинь. Страхование. 6 издание. Пекин: Baodeng Education Press, 2017. C. 28-48.

25. Тан Дуншэн, Чжан Ся. Страховая теория и практика. Пекин: Пекинский технологический институт печати, 2017. С. 50-86.

26. Белозеров С.А., Чернова Г.В., Калайда С.А. Современные факторы развития российского страхового рынка // Страховое дело. 2018. №3. С. 31-35.

\section{References}

1. Adamchuk E.A. Strakhovoe delo [Insurance business]. 2012. N 10-11. P. 30-33.

2. Akimochkin I.V. Strakhovoe delo [Insurance business]. 2010. N 11. P. 50-53.

3. Artemenko D.A., Chililov A.M. Finansy [Finance]. 2019. N 8. P. 58-64.

4. Arkhipov A.P. Finansy [Finance]. 2016. N 11. P. 54-58.

5. Arkhipov A.P. Finansy [Finance]. 2018. N 1. P. 34-38.

6. Bogatenkov A.V. Strakhovoe delo [Insurance business]. 2001. N 12. P. 42-44.

7. Grebenshchikov E.S. Finansy [Finance]. 2019. N 2. P. 44-47.

8. Grebenshchikov E.S. Finansy [Finance]. 2017. N 1. P. 38-44.

9. Kovalevskaya A.S., Feoktistova O.A. Finansy [Finance]. 2017. N 1. P. 45-49. 
10. Levitsky L. Ros. Federatsiya segodnya [Russian Federation today]. 2018. N 6. P. 77-81.

11. Lindenbraten A.L. Zdravookhranenie [Health]. 2015, No. 1, pp. 74-78.

12. Martynova A.A. Finansovoe pravo [Financial Law]. 2019. N 7. P. 44-47.

13. Semenikhin V.V. Strakhovye vznosy [Insurance premiums]. Educational and practical guide. Moscow: GrossMedia, 2017. 462 p.

14. Sidorov S.V., Black N.Yu. Rossiyskiy yuridicheskiy zhurnal [Russian Juridical Journal]. 2017. N 3. P. 164-171.

15. Teslya P.N. ECO. 2016. N 11. P. 22-38.

16. Ma Wenyang Tsifrovaya ekonomika: otkrytie novykh vozmozhnostey $v$ traditsionnykh otraslyakh i novykh formatakh [Digital Economy: Opening New Opportunities in Traditional Industries and New Formats]. Beijing: Democracy and Construction Press, 2017, pp. 207-258.

17. Huang Zhuo Sila tsifrovykh finansov: rasshirenie vozmozhnostey real'noy ekonomiki [The Power of Digital Finance: Empowering the Real Economy]. Beijing: China Renmin University Press, 2018. P. 230-260.

18. Kou Efu Sinyaya kniga strakhovaniya, analiz razvitiya strakhovogo rynka Kitaya [Blue Book of Insurance, Analysis of the Development of China's Insurance Market]. Beijing: China Economic Publishing House, 2017. P. 38-85.

19. Xie Shouguang Sinyaya kniga avtomobilya i strakhovaniya: Otchet o razvitii kitayskogo avtomobilya i strakhovaniya BIG data [Blue Book of Automobile and Insurance: Report on the Development of Chinese Automobile and Insurance BIG data]. Beijing: Social Science Academic Press, 2020, pp. 188-237.

20.Zhao Zhanbo Internet-strakhovanie [Internet Insurance]. Beijing: Capital University of Economics and Business Prss, 2017. P. 3-32.

21. Ma Huateng Tsifrovaya ekonomika: novyy impul's rosta innovatsiy $v$ Kitae [The Digital Economy: A New Impulse for Innovation in China]. Beijing: China CITIC Press, 2017. P. 253-260.

22. Tang Xiao Tsifrovaya ekonomika: novye tekhnologii, novye modeli $i$ novye otrasli, vliyayushchie na budushchee [Digital Economy: New Technologies, New Models and New Industries Influencing the Future]. Beijing, People's Post and Telecommunications Press, 2019, pp. 63-77. 
23.Zhu Jinyuan, Liu Yong, Wei Li Strakhovye tekhnologii [Insurance Technologies]. Beijing: China CITIC Press, 2018. P. 217-257.

24. Wang Xujin Strakhovanie [Insurance]. 6th edition. Beijing: Baodeng Education Press, 2017. P. 28-48.

25. Tang Dongsheng, Zhang Xia Strakhovaya teoriya i praktika [Insurance theory and practice]. Beijing: Beijing Institute of Printing Technology, 2017, pp. 50-86.

26. Belozerov S.A., Chernova G.V., Kalayda S.A. Strakhovoe delo [Insurance business]. 2018. No. 3. P. 31-35.

\section{ДАННЫЕ ОБ АВТОРЕ}

Ван Вэньтао, аспирант кафедры управления рисками и страхования Санкт-Петербургский государственный университет Университетская набережная, 7/9, г. Санкт-Петербург, 199034, Российская Федеращия wwtsen@yandex.ru

\section{DATA ABOUT THE AUTHOR}

Wang Wentao, Graduate Student, Department of Risk Management and Insurance

Saint Petersburg State University

7/9, Universitetskaya embankment, Saint Petersburg, 199034, Russian Federation wwtsen@yandex.ru 